\title{
Szervezeti innováció a Magyar Honvédségben: az ember-gép szimbiózisa a stratégiaelméletek tükrében
}

A stratégia az évezredek folyamán mindig nagymértékben befolyásolta a célkitűzések megvalósítását, az emberek viselkedését, és az összecsapások során a győzelem kivívását. Napjainkban sincs ez másképp, hiszen a digitális technológiai forradalomnak köszönhetően, rendkívül gyorsan következik be a legújabb stratégiai paradigmaváltás, és egyre elképesztőbb kihívásokkal találjuk szembe magunkat, aminek elkerülhetetlen összetevője, hogy bizonytalanságot érzünk.

Véleményem szerint két dolog megváltozott az elmúlt két évtizedben, és ezek kombinációjaként egy a korábbitól eltérő, gyökeresen új hadviselés küszöbén állunk, amelyben az évezredeken keresztül egymástól különálló stratégiai szemléletmódok integrációja, valamint az ember-gép szimbiózisa teljesen új távlatokat nyit a hadviselő felek számára.

Az alábbi cikkben röviden megvizsgálom milyen út vezetett a mai, modern hadviselési elvek létrejöttéig, és milyen technológiai hatások okoztak változásokat a különböző történelmi korokban.

Jelenleg egy újabb stratégiai paradigmaváltás intézményi alkalmazkodás szakaszában járunk, amikor a Magyar Honvédség számára is elengedhetetlen, hogy sikerrel menedzseljen egy digitális transzformációt, és az ezzel együtt járó szervezeti kultúraváltást. A tét óriási! Azok a szervezetek, amelyek képesek sikerrel venni ezt az akadályt, generációs ugrást hajtanak végre, azok pedig, akik elbuknak, letűnt korok szemléletmódjával és módszereivel lesznek kénytelenek felvenni a küzdelmet másokkal szemben.
ÖSSZEFOGLALÁS: A cikk vizsgálja, hogy milyen út vezetett a modern hadviselési elvek létrejöttéig, és milyen technológiai hatások okoztak változásokat a különböző történelmi korokban. Jelenleg egy újabb stratégiai paradigmaváltás intézményi alkalmazkodás szakaszában járunk, a Magyar Honvédség számára is elengedhetetlen, hogy sikerrel menedzseljen egy digitális transzformációt és az ezzel együtt járó szervezeti kultúraváltást. Napjainkban felértékelődik a szemléletmódváltás szerepe, és a nagy méretú bürokratikus szervezetek szinte kivétel nélkül arra törekednek, hogy gyorsabb döntéshozatali folyamatokat, adaptívabb és rugalmasabb szervezeti formákat, valamint hatékonyabb képességfejlesztési módszereket alkalmazzanak. Újra kell gondolni a kutatási-fejlesztési rendszert, és a haderő felszereltségének és reagáló képességének javitása érdekében, a megtartó-fenntartó innovációra fókuszáló technológiai fejlődést kiemelten hangsúlyozó és a tervezésen alapuló stratégai megközelítések helyett, egy innovációs stratégia mentén kell a radikális innovációs megoldásokat bevonva és elötérbe helyezve egy generációs ugrást végrehajtani.

KULCSSZAVAK: Stratégia, innováció, szemléletmódváltás, szervezeti kultúra, technológia, szervezetfejlesztés, vezetés
A Haditechnika folyóirat hasábjain szeretném felhívni a figyelmet arra, hogy az egyre inkább technológia-fókuszú világban, Szun-ce kétezerötszáz évvel ezelőtt született műve óta egy valami nem változott. Alapvetően a hadviselés még mindig az emberi akaratok összecsapásának próbája, és bármennyire is fontos a technológia szerepe, még mindig az ember a meghatározó tényező az összecsapások kimenetelében, még akkor is, ha ezt a gépekkel szimbiózisban hajtja végre. Ezt a gondolatot rendkívül fontos szem előtt tartani, amikor új technológiák beszerzéséről és azok rendszeresítéséről hozunk döntéseket nap, mint nap.

\section{A STRATÉGIAI SZEMLÉLETMÓDOK FEJLŐDÉSE}

A hadelmélet, a történelem és a pszichológia szerint az emberiség fejlődése korszakokra osztható. E korszakok nemcsak a gondolkodásmódban, de a stratégiai megközelítésekben is mindig ugrásszerű fejlődést, paradigmaváltást mutatnak.

Egészen napjainkig alapjában véve két egymástól eltérő szemléletmódot figyelhettünk meg. A bié szemléletmód évszázadokon keresztül egyeduralkodóvá vált a tömeghadseregek körében, ugyanakkor a hagyományostól eltérő, métis szemléletmód, amelyet az irreguláris hadviselő felek sok esetben sikerrel alkalmaztak, a közelmúltban rendkívüli mértékben felértékelődött, és a legújabb generációs hadviselés során integrálódott a bié szemléletmódot

ABSTRACT: The article examines the path leading to the creation of modern warfare principles and the technological effects that caused changes in different historical times. We are currently in the process of institutional readjustment to a new strategic paradigm shift, and it is also imperative for the Hungarian Defence Forces to manage a digital transformation and the associated organizational culture transformation successfully. Today, the role of change of mind is appreciated and the large bureaucratic organizations are almost without exception seeking to adopt faster decision-making processes, more adaptive and flexible organizational forms, and more efficient capability development methods. The $\mathrm{R} \& \mathrm{D}$ system needs to be reconsidered and, in order to improve armament and reaction capability of the armed forces, a generation leap has to be accomplished in harmony with an innovation strategy involving and emphasizing radical innovative solutions, instead of strategic approaches that concentrate on technological development focusing on retentive-sustentative innovation and that is based on planning.

KEY WORDS: Strategy, innovation, change of mind, organizational culture, technology, organization development, leadership

\footnotetext{
Ezredes, Kormánybiztosi Hivatal kutatás-fejlesztési és innovációs szakreferens. ORCID: 0000-0003-1407-0678
} 


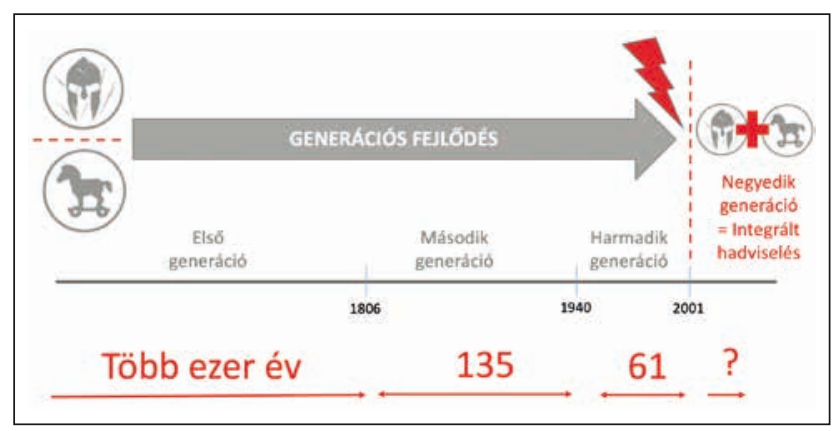

1. ábra. A startégiai elméletek fejlődése

előtérbe helyező tradícionális hadviselésbe. Ehhez az új hadviselési szemléletmódhoz meglehetősen hosszú és rögös út vezetett.

Az első jelentősebb szervezeti formák, amelyek már nagyobb néptömegeket egyesítettek, a törzsközösségek voltak, ahol a törzsfőnökök folyamatosan gyakorolták a hatalmukat, hogy kordában tartsák a csapatukat, így ebben az időszakban a megfélemlítés volt a mozgatórugó. Ebből az időből származnak az első írásos emlékeink is, amelyekből kiderül, hogy a közelharcra, a hősies helytállásra és a győztes csaták megvívására összpontosító hadművészet az ókori hadviselő felek hagyatéka. ${ }^{1}$

Ebben a korban a nyers erő (bié) szemléletmód és a falanx típusú harcászat terjedt el, amelyet az ókori Spárta fejlesztett tökélyre. A spártai falanx modellje a hoplita nehézgyalogosok hármas jelszava: fegyelem, közösség, önzetlenség volt. Ezek az eszmék napjainkig jól kifejezik az első generációs hadviselés alapelveit. Ez a fajta harcmodor megkövetelte, hogy valamennyi katona egységes egészként gondolkodjon és cselekedjen, ugyanakkor az egyes személyek közötti küzdelem is komoly jelentőséggel bírt. Ezek a követelmények és eszmék határozták meg a harcoló felek szemléletmódját és kiképzését, és adódtak tovább a történelem folyamán.

Az első generációs hadviselés éppen ezért viszonylag észszerűnek mondható környezeti körülmények között zajlott és kötött szabályokon alapult: mindenki ismerte a feladatát, begyakorolta a tennivalóját, és a szemben álló csoportok tagjai bizonyos rituálékat követően, viszonylag kiszámítható módon, egy meghatározott szabályrendszer mentén hajtották végre az összecsapást. Nem volt ez másként még ezer évvel később sem, amikor megjelentek az első tömeghadseregek és olyan szervezeti formák alakultak ki, amelyeket a mai bürokráciák őseinek tekinthetünk.

Ekkor figyelhetjük meg, hogy egyre bonyolultabbá válik a hadviselés környezete, éppen ezért a tervezési és végrehajtási funkciókat teljesen szétválasztották. A tervezés és a gondolkodás a piramis tetején elhelyezkedő szűk csoport feladata lett, és ezeket a terveket a piramis alján elhelyezkedő réteg valósította meg. A sikeres végrehajtás érdekében folyamatokat dolgoztak ki, amelyeket egy középső (ma úgy mondanánk, menedzsment) réteg felügyelt. Így bizonyos munkafolyamatok standardizálhatóvá és bárhol megismételhetővé váltak, ez pedig komoly befolyást gyakorolt a vezetési elvekre.

A 17. század közepén a legtöbb háborúban még mindig a falanx mintáját követő vonalas harcászatot tökéletesítve vezették győzelemre a tábornokok csapataikat, Bonaparte Napóleon azonban forradalmasította a hadviselést és az 1805-ös hadjárata során kialakította a hadtestek rendszerét, ezzel rugalmasságot kölcsönözve a hadsereg számára. A francia tábornok ösztönösen értette, hogy a merev szervezeti forma korlátozza a lehetséges opciókat, ezzel szem- ben egy részekre felosztott hadsereg számtalan lehetőséget rejt magában. A szervezeti felépítés megváltoztatása, ahogyan azt Napóleon Jénánál, a poroszokat legyőzve be is bizonyította, rendkívül fontos összetevője volt a stratégiának.

A Napóleon nevével fémjelzett paradigmaváltás a hadviselésben a hadtudomány jelentős fejlődését és kibontakozását jelentette. ${ }^{2}$ Ebben az időszakban a hadvezérek a hadműveletek során a bőséges anyagi erőforrások elosztásának gondos kiszámításával igyekezték elkerülni a váratlanságot. Mindezekből adódik, hogy a lényeg nem az improvizáció, hanem a pontos terv volt, amelyet az alárendeltek igyekeztek szóról szóra követni. Ha jobban belegondolunk, ez nem sok szemléletmódbeli eltérést mutat az első generációs bürokratikus szervezetekhez képest, amelyekben egy szűk felső réteg iránymutatását követve kellett mindenkinek végrehajtania az utasításokat.

A szabálykövetésen, és számítások, valamint tervek készítésén alapuló parancsnoki képességek sokkal fontosabbak voltak, mint a kreativitás. ${ }^{3}$ Ebből adódik e hadviselési forma hátránya is: a változó környezethez való lassú és nehézkes alkalmazkodás. Az iparosodás korában a hatalmas gépezetként, olajozottan működő szervezeti formák pontosan így működtek, ugyanakkor az idő előrehaladtával változásokat is megfigyelhetünk.

Először is megváltozott a szervezetben dolgozók felelősségvállalása, és a parancsuralmi rendszerek helyett bizonyos haderőkben újabb paradigmaváltásra került sor. $A z$ úgynevezett küldetésorientált vezetésszemlélet az iránymutatást és a decentralizált végrehajtást helyezte előtérbe. Ebben a rendszerben a stratégiát az alárendelt parancsnokok értelmezték és lebontották a saját szintjüknek megfelelően, meghatározták az elérendő célkitűzések mértékét, illetve idejét, de nem követték folyamatosan nyomon a csapatukban dolgozó emberek teljesítményét.

Ez a fajta gondolkodásmód különösképpen megfigyelhető volt a porosz hadseregben, amely a jénai vereség után úgy döntött, hogy ideje véget vetni a múltban gyökerező merev szervezeti formáknak, és haladéktalanul hozzálátott a haderő szervezeti átalakításához. A poroszok sikerének titka abban rejlett, hogy rendkívül nagy hangsúlyt fektettek a tisztek oktatására, akiket a stratégia, a harcászat és a vezetéselmélet területein a lehető legjobban felkészítettek. Hangsúlyosan arra törekedtek, hogy a kiképzés során tanuljanak a saját és mások hibáiból, és folyamatosan fejlesszék ismereteiket. Ez a gondolkodásmód vezetett el a hadviselés harmadik generációjához, az Auftragstaktik, vagyis a küldetésen alapuló szemléletmód elterjedéséhez. Bár magát a szemléletmódot már az ezernyolcszázas évek második felében tesztelni kezdték, mégis a második világháború idejére nyerte el igazi, végső formáját, és Liddell Hart munkásságának köszönhetően világszerte ismertté vált.

E brit katona és hadtudós 1967-ben megjelent könyvében ${ }^{4}$, az általa indirekt megközelítésnek nevezett stratégia lényegét a következőkben látta: ha a célokat az eszközökhöz rögzítjük, ha mindig szem előtt tartjuk a célt, ha a legváratlanabb irányból támadunk, ha olyan helyzeteket teremtünk, amelyekből többféle eredmény kihozható. Persze mindennek feltétele, hogy az általunk vezetett szervezet kellőképpen rugalmas és alakítható legyen.

$\mathrm{Az}$ indirekt hadviselést a két világháború között a német haderő fejlesztette tovább. Céljuk az ellenfél sebességgel és tempóval történő kizökkentése és az indirekt támadás középpontba helyezése volt. Ez a hadviselési forma a villámháború (Blitzkrieg) idején bebizonyította, hogy a sikert nem az erőforrások abszolút fölényével, hanem az ellenség 
gyenge pontjai ellen intézett lendületes támadással lehet kivívni. A gyors ütemű, sikert sikerre halmozó, egyszerre több helyen indított támadás következtében az ellenség feletti fölényt nem katonai erővel, hanem a kedvező feltételek kialakításával (a kezdeményezés megragadásával) és a lehetőségek azonnali, minden késlekedés nélküli kihasználásával teremti meg. ${ }^{5}$

E hadviselési forma szerint háborúban nem léteznek előre kiszámítható helyzetek, ezért a támadás valamennyi mozzanatára precíz hadműveleti tervet sem lehet kidolgozni. Ehelyett a vezetés folyamatát és a döntési szinteket kell decentralizálni, vagyis a tábornokoknak lehetővé kell tenniük alárendeltjeik számára, hogy (a vezetői szándék ismeretében) önálló döntéseket hozzanak. Ennek eredményeként az alárendelt parancsnokok - a felgyorsult döntéshozatal érdekében, kellő információk hiányában - kreatív módon a váratlanul alakuló lehetőségek megragadására törekednek. Ez rendkívül magas követelményeket támaszt a vezetőkkel szemben, és az ésszerűen kockáztató parancsnok válik hadviselés központi alakjává. ${ }^{6}$

A harmadik generációs hadviselést jellemző szemléletmód éltető ereje az időelőny megszerzése, mivel ennek birtokában a támadó megfosztja ellenfelét az ellenállás megszervezéséhez szükséges időtől, így ő diktálja a feltételeket, ezáltal stratégiai előnyt kovácsol magának.

Így érkeztünk el a 21. század küszöbére, amikor újabb stratégiai paradigmaváltásnak lehetünk szemtanúi. A legújabb generációs váltást az fémjelzi, hogy az évszázadokon keresztül egymás mellett létező tradícionális (bié) és irreguláris (métis) szemléletmódok, amelyek a történelem folyamán jól elkülöníthetőek voltak, a negyedik ipari forradalom által képviselt technológiai változások hatására egyre jobban elterjednek, és az elmúlt húsz évben olyan integrált irányba tolják el a hadviselést, ahol a bié és métis egyszerre, egymással szimbiózisban van jelen.

$\mathrm{Az}$ integrált hadviselés legfőbb jellegzetessége, hogy komplexebb, de gyorsabb lefolyású válsághelyzetek kialakulását teszi lehetővé, amelyekkel szemben a jelenlegi tradicionális döntéshozatali és válságreagálási modellek nem képesek időben és hatékonyan fellépni.

Az integrált hadviselés modern változatának koncepcióját az ezredforduló elején két kínai ezredes tette közzé egy korlátok nélküli hadviselésről ${ }^{8}$ szóló tanulmányban. Az elméleti megközelítés a különböző hadviselési formák integrációjának lehetőségére és a különböző hadszíntereken folytatott tevékenységek ötvözésére és együttes alkalmazására tett javaslatot. A határok nélküli hadviselés legfontosabb alapelvei ${ }^{9}$ a mindenirányúság, a szinkronicitás és az aszimmetria.

A mindenirányúság azt jelenti, hogy a győzelem kivívásához valamennyi hadszíntér lefedése, illetve a háborús aspektusok széles körének (politikai, gazdasági, kulturális területek) teljes (totális háború keretében történő) kiaknázása szükséges. A szinkronicitás a hadszínterek széles tárházát felhasználó műveletek egyszerre, egymással egy időben történő alkalmazására hívja fel a figyelmet. E két alapelv mentén kombinálják a tradícionális és az irreguláris hadikultúrák erősségeit, így téve lehetővé egy integrált megközelítést. Végezetül az aszimmetria az információs fölény kialakítását és folyamatos fenntartását tűzi ki célul annak érdekében, hogy a különböző célcsoportokat hatékonyan befolyásolni tudják a müveletek valamennyi időszakában.

Az integrált hadviselés megjelenésével olyan helyzet alakult ki, amelyben kiszámíthatatlan viszonyok között és nagyon gyorsan kell reagálni általában olyan környezetben, ami már nem békeállapot, de még nem is háború, így nagyon nehéz megtalálni azokat az elemeket és összetevőket, amelyek aktivizálásával hatékonyan válaszolhatunk egy stratégiai kihívásra. ${ }^{10} \mathrm{Nem}$ csoda, hogy válaszadás tekintetében a bürokratikus alapokon szerveződő haderők napjainkban kiemelt kérdésként kezelik a reagálóképesség növelését, és keresik a megoldásokat, hogyan is tudnák sikerrel végrehajtani a digitalis transzformációt a haderőben.

\section{A technológIa És aZ ÜZletI STRATÉGIa FEJLődÉsE}

A tradícionális üzleti stratégia fejlődéstörténete viszonylag szűkebb idősávon követhető végig, mint a hadviselésé, de szorosan összefügg azzal, hiszen a történelem folyamán megfigyelhető, hogy a katonai stratégia mentén alakultak ki a jelenleg is ismert üzleti stratégiai megközelítések.

A hadviselésben bekövetkező paradigmaváltásokhoz hasonlóan az üzleti életben is bekövetkezett néhány nagyobb horderejü forradalmi változás. ${ }^{11}$ Az üzleti forradalmak mindegyikére jellemző, hogy alapjában véve két periódusra oszthatók fel: alkalmazási és fejlődési szakaszra. $\mathrm{Az}$ alkalmazási szakasz során a technológiai fejlődés megugrását a befektetés robbanásszerű növekedése váltja fel. Ezt követi a fejlődési szakasz, amikor a technológiát széles körben alkalmazni kezdik. Az alkalmazási és a fejlődési szakasz közt található egy fordulópont, az intézményi alkalmazkodás, amikor a szervezetek alkalmazkodnak az új technológiához, hiszen a megváltozott körülményeknek köszönhetően kénytelenek új vállalati startégiát és struktúrát kitalálni, és ezeket a gyakorlatba is átültetni.

Az elmúlt kétszáznegyven évben az intézményi alkalmazkodási szakasz során a szervezeteknek többször módosítaniuk kellett vállalati stratégiájukat, hogy meg tudjanak birkózni a soron következő technológiai változásokkal. A vállalati stratégia változása szinte minden esetben struktúraváltást eredményezett. Ezen strukturális változások közül három szakaszon vagyunk túl, és jelenleg a negyedik közepén tartunk. Ezt az intézményi alkalmazkodási folyamatot nevezik sokan digitális transzformációnak.

A kereskedelem első időszakában a legtöbb vállalkozás általános kereskedés volt: termékeket vásárolt és adott el exportőrként, nagykereskedőként vagy importőrként. Az 1840-es évekre a vállalatok azonban elkezdtek egy adott termékre szakosodni (például gyapotra), és a terméklánc egy szakaszára (például a behozatalra, vagy disztribúcióra) koncentráltak. Ez az átmenet az általánostól a szakosodott kereskedőkre volt az első strukturális változás az üzleti életben. Bár ezek a szervezetek még mindig kis, helyi vállalkozások voltak, a tulajdonos és a menedzsment pedig a legtöbb esetben egy és ugyanaz a személy, a tulajdonosok irányították az üzletet, és nem voltak fizetett középvezetők, adminisztrátorok.

Ezt váltotta fel az iparosodás elterjedésével a munkakörök és a szerepkörök szerinti csoportosítás és a standardizált folyamatok mentén történő munkavégzés. A 19. század közepétől, a vasút megjelenésével a vállalatok nagyon gyorsan országos lefedettségre tettek szert, és a 19. század utolsó negyedére, amely az acél és nehézipar koraként vonult be a történelembe, tanúi lehettünk a nemzeti vállalatok elterjedésének.

Ebben a korszakban olyan iparágak fejlődésének köszönhetően, mint a vasút, az acélipar, a távíró, a húscsomagolás, az egyre növekvő szervezetek egyre nehezebben birkóztak meg a nagy méretből, fölrajzi elhelyezkedésből, horizontális és vertikális integrációból fakadó megnövekedett szervezeti igényekkel, amelyek bonyolulttá tették a szervezeti formát. A kihívás a megnövekedett méretű haderőkhöz hasonlóan abban állt, hogy egyre több szervezeti 
egységet kellett egyetlen közös egységként összehangolni és egységesen működtetni.

A napóleoni hadseregektől ellesett hadseregszervezést alkalmazva, az új vállalati stratégiák arra ösztönözték a vállalkozásokat, hogy funkciók mentén (mint például a termelés vagy értékesítés) építsenek fel struktúrákat, hivatásos vezetőket képezzenek, valamint vezetési hierarchiákat építsenek ki e struktúrák működtetésére. Kevesebb, mint ötven évvel később, a 20. század kezdetére kialakult a modern vállalati forma. ${ }^{12}$ A kisvállalkozásoktól a funkciók mentén szerveződő vállalatokig történő átmenet volt tehát a második stratégiai adaptáció az üzleti életben.

Az újabb fejlődést az autó és az olaj korában a közlekedés és a szállítás forradalma hozta magával. Ebben a korban, az 1920-as évekre újabb stratégiai kihívással néztek szembe a nagyvállalatok. Világszerte, de különösen az Amerikai Egyesült Államokban a fizikai távolságok korlátozták a napi szintű, közvetlen irányítást, a cégek pedig egyre inkább elaprózott termékvonalakat képviseltek.

Erre válaszul következett be a harmadik stratégiai alkalmazkodás a nagyvállalatok szervezeti felépítésében: a monolitikus, funkcionális vonalak mentén szerveződő vállalatok operatív divíziók szerint (mint például termék) vagy földrajzi elhelyezkedés szerint szerveződtek újjá. Ebben az új felállásban mindegyik szervezeti elem felelősséget érzett saját nyeresége és vesztesége iránt. A funkcionális szervezetektől az operatív divíziókba történő stratégiai strukturális átmenetet ${ }^{13}$ a General Motors tette népszerűvé, majd hamarosan követte példáját a Standard Oil, a Sears és egyéb nagyvállalatok is.

Ebben az időszakban az operatív divíziók mentén szerveződő nagyvállalatok egyre nagyobb hangsúlyt fektettek a vállalati stratégia megalkotására és kivitelezésére. A vállalati stratégia fogalmát Igor Ansoff alkotta meg az 1950-es években, ${ }^{14}$ és számos jelenleg is használatban lévő modell és elmélet az ő munkájára vezethető vissza.

Ezt követően terjedt el Michael E. Porter versenystratégia koncepciója. ${ }^{15} \mathrm{~A}$ versenystratégia teremtette meg az alapot az árversenyhez és a minőségi megkülönböztetésen alapuló stratégiához, azokhoz az alapelvekhez, amelyeket a nagyvállalatok döntő többsége még ma is előszeretettel alkalmaz, és a hadviselés stratégiai gondolatai visszaköszönnek a koncepcióban. ${ }^{16}$

A környezeti tényezőket figyelembe véve Porter arra a feltételezésre alapoz, hogy a viszonyok kiszámíthatók, a stratégiai tervezés folyamatával kapcsolatban pedig olyan rendszert javasol, ami lineáris és tervezésen alapul, jól elválasztva a stratégiaalkotás és a végrehajtás lépéseit. Porter versenystratégiája meghatározó jelentőségünek számított az üzleti életben és a legtöbb modell, amely a versenyképesség tartós megteremtésének fenntartására törekedett, ebből indult ki.

E modelleket figyelembe véve nem meglepő, hogy az elmúlt évszázad mai szemmel nézve viszonylag lassú technológiai fejlődése mellett a kiszámíthatóbb környezetben a tradicionális szemléletmódot képviselő módszerek jól működtek. Éppen ezért válhatott egyeduralkodóvá az mind a hadviselésben, mind pedig az üzleti életben, hiszen a logikai alapon végzett tervezési folyamatok kiszámítható eredményeket voltak képesek produkálni hosszabb távon is.

A 20. században az iparosodás korszakára jellemző szemléletmódot képviselő vezetők abból indultak ki, hogy van idejük a képességek kifejlesztésére, az intézményi adaptáció végrehajtására, így gondos tervezés eredményeképpen arra törekedtek, hogy a stratégiai terv mentén hajtsák végre a fejlesztési folyamatokat, így az elmúlt év-

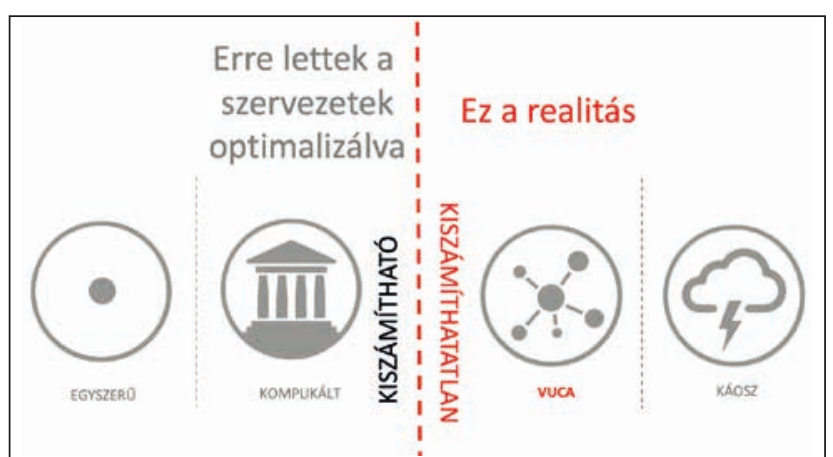

2. ábra. A kiszámíthatatlan környezet

század vége felé a stratégiai stabilitásra való törekvés volt a meghatározó.

Így érkeztünk el az ezredfordulóhoz, amikor a hierarchikus szervezeti struktúrák kezdték elveszíteni versenyelőnyüket. A vezetők az új évezredben arra lettek figyelmesek, hogy a bürokratikus szervezeti formák egyre nehezebben képesek megbirkózni a sokkal agilisabb, gyorsabb döntéshozatali folyamatokat futtató rugalmas szervezetekkel, és nem képesek a megváltozott környezeti viszonyok között tartós versenyelőnyt fenntartani tradicionális módszerekkel.

$A z$ ezredfordulón a hadviselésben a gerilla- és terrormozgalmak elterjedése okozott egyre nagyobb problémát. Az üzleti életben a jelenleg is tartó technológiai forradalom, amely az információtechnológia, telekommunikáció, a bioés nanotechnológia ugrásszerű fejlődését hozta magával, hatással volt a már meglévőkre is, és egyre inkább a kockázati tőke által finanszírozott startup vállalkozások térnyerése és megerősödése volt megfigyelhető.

Az intézményi adaptáció viszonylag hosszadalmas folyamat, éppen ezért a legtöbb nagyvállalat még mindig az elmúlt évszázadra jellemző tradícionális elvek szerint szervezi és valósítja meg a stratégiáját, és nem veszi észre, hogy a valódi stratégiai kockázat a változás elkerülésében rejlik.

Megfigyelhető azonban egy újfajta, innováción alapuló stratégiai szemléletmód is, hiszen az egyre kiszámíthatatlanabbá váló környezeti viszonyok között a vállalati vezetők elkezdtek alternatív stratégiai megközelítéseken gondolkodni. Itt érkezünk el ahhoz a ponthoz, ahol a negyedik generációs hadviselés stratégiai elméletei ismételten hatással lehetnek az üzleti életre.

\section{NAPJAINK STRATÉGIAI KIHIVÁSA}

Az üzleti életben az ezredfordulót követően sokan próbálták serkenteni az innovációt annak érdekében, hogy a gigantikus szervezetek képessé váljanak a dinamikusan változó környezeti kihívások kezelésére, a szervezeti változások időbeni végrehajtására és a stratégia szükség szerinti módosítására.

E szervezetek döntő többsége azért küzd, hogy lépést tartson a felfokozott tempót diktáló, kockázati tőke által támogatott startup vállalkozásokkal. ${ }^{17} \mathrm{~A}$ stratégiai kockázat igen nagy, hiszen míg egy évszázaddal ezelőtt a top ötszáz nagyvállalat átlagosan hatvanhét évig volt képes a listán maradni, addig napjainkban ez a szám tizennégy év. ${ }^{18}$ Amennyiben ez nem lenne éppen elég probléma, a kérészéletű nagyvállalatok mellett megjelennek az olyan villámgyors globális térhódításra képes trónkövetelők, mint az Uber, vagy az Airbnb, amelyek az irreguláris hadviselő felekre jellemző gondolkodásmóddal, és a mozgalmakhoz hasonló szervezeti és vezetési módszerekkel komplett 
iparágakat képesek egy-két év leforgása alatt felbolygatni. Mindez a tradicionális szemléletű nagyvállalatokat arra kényszeríti, hogy stratégiájukat és üzleti modelljüket rendszeresen felülvizsgálják.

Ebben a szélesebb spektrumú, folyamatosan változó, dinamikus környezetben egyértelműen összekapcsolódik a védelmi és az üzleti stratégiai problémaforrás. Napjainkban a hadviselés történetének egyik legnagyobb szemléletmódváltását, a bié és métis szemléletmódok integrációját figyelhetjük meg, ugyanakkor az üzleti élet fejlődéstörténetét tekintve a negyedik strukturális adaptációs folyamat kellős közepén tartunk, ${ }^{19} \mathrm{~s}$ úgy tűnik, hogy az emberiség képtelen lépést tartani a technológia fejlődési ütemével.

Éppen ezért felértékelődik szemléletmódváltás szerepe, és a nagyméretű bürokratikus szervezetek szinte kivétel nélkül arra törekednek, hogy gyorsabb döntéshozatali folyamatokat, adaptívabb és rugalmasabb szervezeti formákat, valamint hatékonyabb képességfejlesztési módszereket alkalmazzanak a versenyképesség fenntartására. Ez pedig egy újabb alapvető stratégiai kihívás elé állítja a döntéshozókat, ami a sebességgel kapcsolatos.

Úgy érezzük, hogy minden felgyorsul körülöttünk, és az egyes ciklusidők (a szervezeti-intézményi alkalmazkodáshoz rendelkezésre álló időtartamok) rövidülnek, mindez pedig kiszámíthatatlansághoz vezet.

A vezetők folyamatosan azzal küzdenek, hogy nem képesek kellő gyorsasággal reagálni a környezetben bekövetkező változásokra. Valójában azonban arról van szó, hogy az emberi alkalmazkodóképesség nem képes lépést tartani a technológiai forradalom exponenciális növekedésével és az ezáltal keletkező információmennyiséggel, ${ }^{20}$ ez pedig kibillent bennünket az egyensúlyunkból.

Mindez azt jelenti, hogy ha nem vagyunk képesek valahogyan felgyorsítani az egyéni és szervezeti tanulási folyamatokat, akkor végérvényesen lemaradunk ebben a versenyben és óhatatlanul a technológia győzedelmeskedik az emberiség felett. Ezen probléma kezeléséhez a hagyományostól eltérő folyamatokra és az innovációra van szükség, illetve olyan emberi képességek fejlesztésére kell koncentrálnunk, mint a problémamegoldás, kritikus gondolkodás, kreativitás, hálózatépítés és a változó körülményekhez való gyors és megfelelő alkalmazkodás. ${ }^{21}$

A valóság azonban az, hogy a nagy méretű bürokratikus szervezetek, közöttük a Magyar Honvédség is, a környezeti változások ellenére továbbra is történelmi távlatokból indulnak ki. Igazuk is van abban a tekintetben, hogy eddig minden intézményi kiigazítás jó ideig elhúzódott, és nem igényelt valódi innovációt. Az acél és nehézipar korában a független feltalálóknak és kis méretű cégeknek köszönhetően az innováció elsősorban a vállalaton kívül zajlott. Az

\section{3. ábra. Az adaptációs képesség fejlődése}

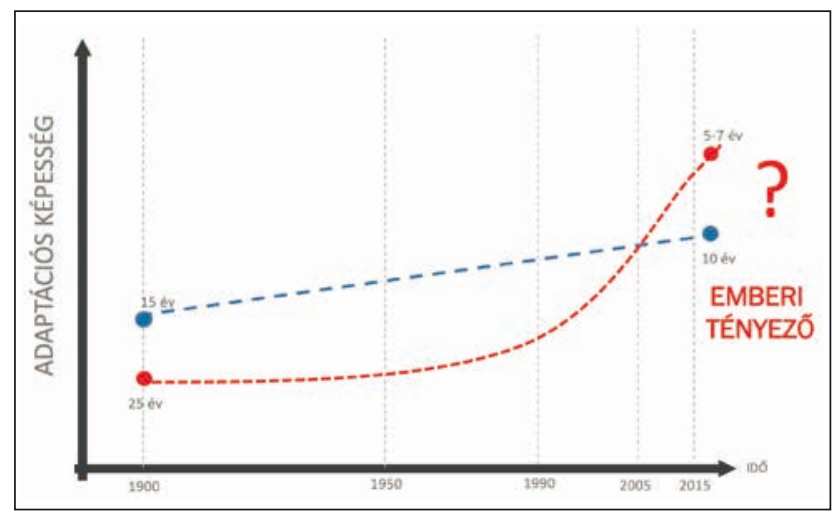

automobil és az olaj korában azonban a nagyvállalatok törekedni kezdtek a termékfejlesztési folyamat irányítására. Ennek érdekében az innovációt és a fejlesztést bevonták a vállalatba, vállalati kutatási és fejlesztési $(K+F)$ részlegeket hoztak létre ${ }^{22}$, amelyek az elmúlt évszázad közepére átvették a feltalálók, vállalkozók helyét. ${ }^{23}$ Ebben az időszakban elsősorban a vállalati $\mathrm{K}+\mathrm{F}$ laborok szabták meg a fejlesztés ütemét.

A legtöbb bürokratikus szervezet ezt az elvet követi manapság is, az ezredfordulón azonban az információtechnológia és telekommunikáció korában azonban a kockázati tőke által finanszírozott startupok kezdték elárasztani a piacot, ${ }^{24}$ így a vállalati $\mathrm{K}+\mathrm{F}$ csoportok, amelyek az előző ötven évben sikeresnek bizonyultak, hirtelen azzal szembesültek, hogy a hagyományosan sikeresnek tekinthető módszerek többé nem működtek.

Történelmi viszonylatban a vállalati $\mathrm{K}+\mathrm{F}$ csoportok nagy gyakorlatra tettek szert abban, hogy elemezzék versenytársaikat, a trendeket, az új technológiákat és a vállalat üzletmenetére radikálisan ható tényezőket, megbízatásuk azonban arra szólt, hogy figyeljék a látóhatárt. Így a vállalati $\mathrm{K}+\mathrm{F}$ az új technológiai ciklus és a startup vállalkozások helyett a legutóbbi technológiai ciklusra és azok meglévő képviselőire fordították elsősorban a figyelmüket, és egyre többször elmulasztották a negyedik ipari forradalomban kínálkozó forradalmi lehetőségeket.

Az elmúlt húsz évben számtalan területen tapasztalható fejlődés. ${ }^{25}$ Az energetika például, ami számos egyéb tudományterület mozgatója, látványos átalakuláson megy keresztül. A változások minden fejlődő tudományterületen - a biotechnológia, a robotika, az információ, a nanotechnológia, az energetika (röviden: BRINE) területén - figyelmet érdemelnek, és ezeknek az újszerü technológiáknak az összekapcsolásával, azok interakciói mentén számos robbanásszerű változásra lehet számítani a közeljövőben, amely hatással van a hadviselésre is. Szemünk láttára körvonalazódik az ember-gép szimbiózisa, amelynek eredménye a robotika térnyerése, a munkahelyeket veszélyeztető automatizáció, valamint a mesterséges intelligencia és a kiterjesztett valóság technológiai megoldásainak beépülése a mindennapjainkba.

A Magyar Honvédség is folyamatosan érzi a nyomást, amit az új technológiák, valamint az újonnan megjelenő szereplők mindent elsöprő áradata jelent. Az ezredfordulót követő időszakban, amíg a startup vállalkozásokat egyre növekvő befektetési hullámok finanszírozták, a haderő tudomást sem vett a bennük rejlő lehetőségekről. Napjainkban azonban a „digitális darwinizmus” viszonyai között kell a folyamatos megújulásra törekednünk, amely nem valósítható meg a régi szervezeti keretek között és egy tradicionális stratégia mentén.

A probléma nagyon egyszerü: a startup vállalkozások, akárcsak az irreguláris hadviselő felek, sokkal agilisabban és rugalmasabban közelítik meg a problémákat és a nagyvállalatok tervezésen alapuló rendszerei egyszerűen képtelenek követni ezt a tempót. A vállalati kockázati tőke átfutási ideje, az általunk jelenleg alkalmazott beszerzési módszerek és szabályzók túl hosszúnak bizonyulnak ahhoz, hogy reagálni tudjanak a változásokra és kifizetődők legyenek.

Ez a haderőben jelen lévő $K+F$ szervezetek tekintetében azt jelenti, hogy egyre több figyelmet fordítanak a fejlesztésre és jóval kevesebbet a kutatásra. Ez pedig elvezet odáig, hogy a kutatók rövid távú, horizont 1 típusú problémákra, vagyis a létező technológia javítására (többnyire műszaki fejlesztésekre) keresik a megoldást, ahelyett, hogy a következő technológiai ciklus potenciálisan radikális újí- 


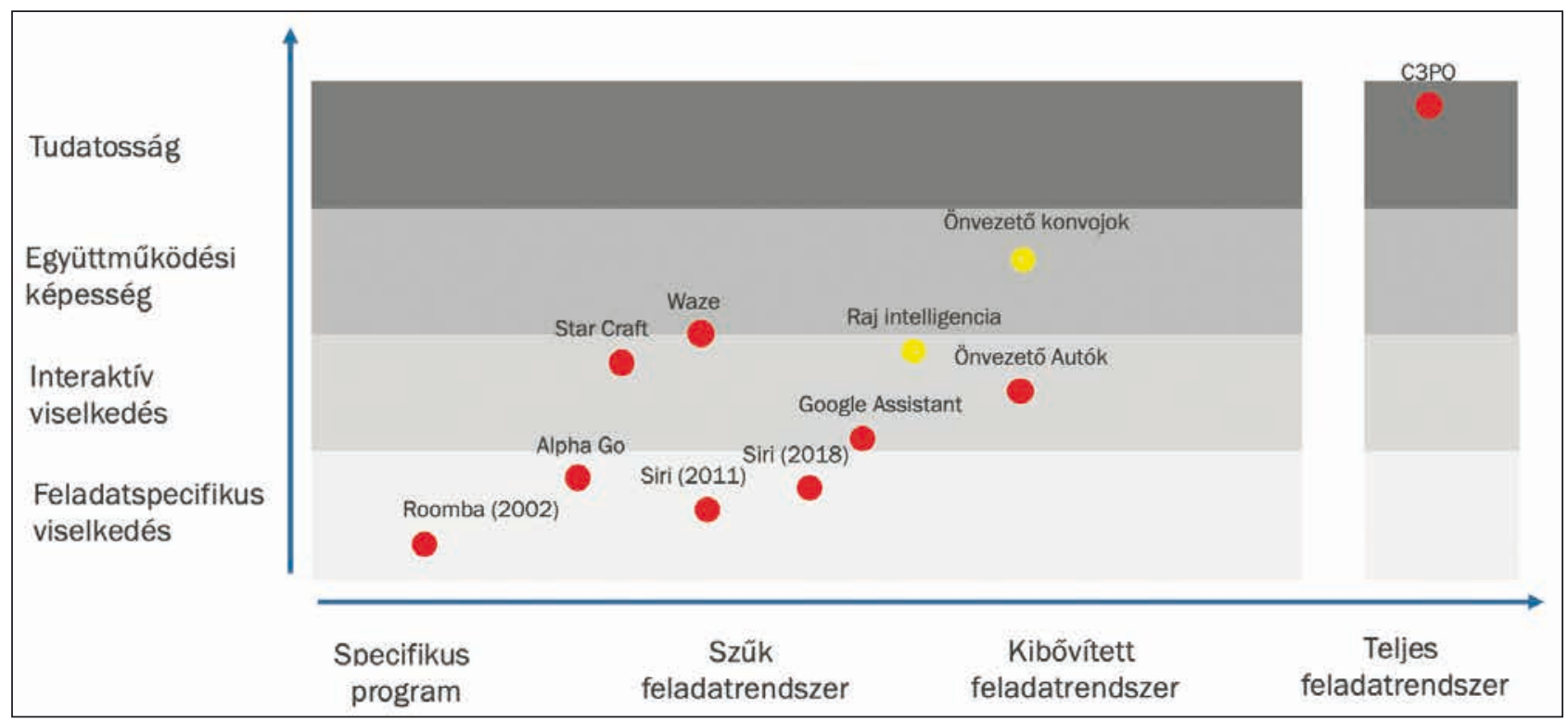

\section{4. ábra. Ember-gép együttműködése}

tást hozó, horizont 2 és horizont 3 típusú elképzelésein dolgoznának.

Nem csoda, hogy az igazán innovatív kutatók, akik a jövő nagy áttörését akarják megvalósítani, nem akarnak ilyen közegben dolgozni. Ezek az emberek a gerilla mozgalmakhoz hasonló startup vállalkozásban találnak számukra megfelelő kihívásokat, vagy saját vállalatot alapítanak.

A nagyvállalatok $\mathrm{K}+\mathrm{F}$ szervezeteinél a megtartó-fenntartó innováció vált a stratégiaalkotás alapjává, amely a meglévő üzleti modellek, valamint termékek és folyamatos bevételi források élettartamát védte és hosszabbította meg. Ez a fajta stratégiai megközelítés tönkretette a hosszú távú innovációt, hiszen szinte teljesen figyelmen kívül hagyta a következő technológiai ciklusba történő befektetést.

Aggasztó az is, hogy a megtartó-fenntartó innovációs kezdeményezések jelentős százaléka sikertelennek bizonyul, valamint a radikálisan újító kutatásokba és az üzleti modell innovációjába történő befektetés továbbra is hanyatlik. ${ }^{26}$ Mivel a horizont 1 fókuszú stratégiák egyre kevésbé életképesek, a tipikus vállalati $\mathrm{K}+\mathrm{F}$ szervezet nem tud lépést tartani az exponenciális technológiákkal ez pedig azt eredményezi, hogy a haderő nem képes generációs ugrást végrehajtani, ezáltal pedig eleve hátrányból indul minden összecsapás során azokkal szemben, akik sikeresen végrehajtottak egy innovációs stratégiával támogatott digitális transzformációt.

\section{ÖSSZEGZETT KöVETKEZTETÉSEK - SZEMLÉLETMÓdVÁLTÁS ÉS DIGITÁLIS TRANSZFORMÁCIÓ}

A 21. század biztonsági környezetét a globalizáció és az exponenciálisan gyorsuló változások hatásai formálják. Ezek a változások a hagyományos szembenállás mellett az új típusú és egyre összetettebb környezet kihívásaival kényszerítik szembenézni a nemzeteket a hatékony és megfelelő védelem biztosítása érdekében.

Miközben az elmúlt évtizedek védelmi reformjai a Magyar Honvédség humán és technikai eszközállományának erodálódását eredményezték, addig a kormánynak a Magyar Honvédség megújítása érdekében a Zrínyi 2026 programon keresztüli elkötelezettsége egy olyan páratlan lehetőséget biztosít, amelyet megfelelően kiaknázva generáci- ós ugrást hajthatunk végre a tudásbázis megújítása, valamint a technológiai felszerelés innovatív alkalmazása tekintetében.

A védelmi innovációs elképzelésekkel kapcsolatosan megfogalmazott határozott kormányzati szándék a hazai gyártókapacitás fejlesztése. Ennek érdekében a jelenlegi kutatás-fejlesztési rendszer újragondolására van szükség. A megtartó-fenntartó innovációra fókuszáló technológiai fejlődést előtérbe helyező és a tervezésen alapuló stratégai megközelítések helyett egy új innovációs stratégiára van szükség, amely a radikális innovációs megoldásokat bevonva képes a haderő szerkezetét átalakítani, és biztosítja a feltételeket a generációs ugrás végrehajtásához.

Az új innovációs stratégia megvalósítása érdekében a radikális megoldások kidolgozására és támogatására újrastrukturált szervezetet és olyan központokat kell létrehozni, amelyek biztosítják a képességfejlesztések összekapcsolását a startup ökoszisztémával, hiszen szükség van a hazai ipar (kkv-k és startup vállalkozások) bevonására a védelmi ipari fejlesztésekbe.

Ezen kihívás két rendkívül fontos stratégiai változást igényel. Az egyik, egy környezetváltozás által indukált folyamat, amelyre a megoldás a szemléletmódváltás, a bié és métis szemléletmódok integrálása, amelynek során változtatni kell a szervezeti felépítésen, a döntéshozatali folyamatokon és magán a szervezeti kultúrán is.

A másik egy technológiai fejlődés által vezérelt folyamat, amelynek során az ember-gép szimbiózisát kell megvalósítani egy digitális transzformáció keretében úgy, hogy közben felismerjük: a hadviselés során a döntő tényező még mindig az ember. Az összecsapások során az győzedelmeskedik, aki képes az innovatív technológiai megoldásokat gyorsabban eljuttatni a végfelhasználóhoz (az operátorhoz), illetve proaktív módon felmérve a helyzetet az akaratát rákényszeríteni a szembenálló félre, villámgyorsan cselekedve és a cselekedeteket követően a tapasztalatokat mindenki másnál gyorsabban feldolgozva újraindítja a folyamatot. Ebben a folyamatban rendkívül nagy szerepe van a modern technológiának, de az csupán eszköz az emberek kezében.

Mindez, alapjában véve egy szemléletmódváltást jelent, hiszen olyan digitális transzformációt kell végrehajtani a Magyar Honvédségen belül, mintha egy óriási hadsereg próbál- 


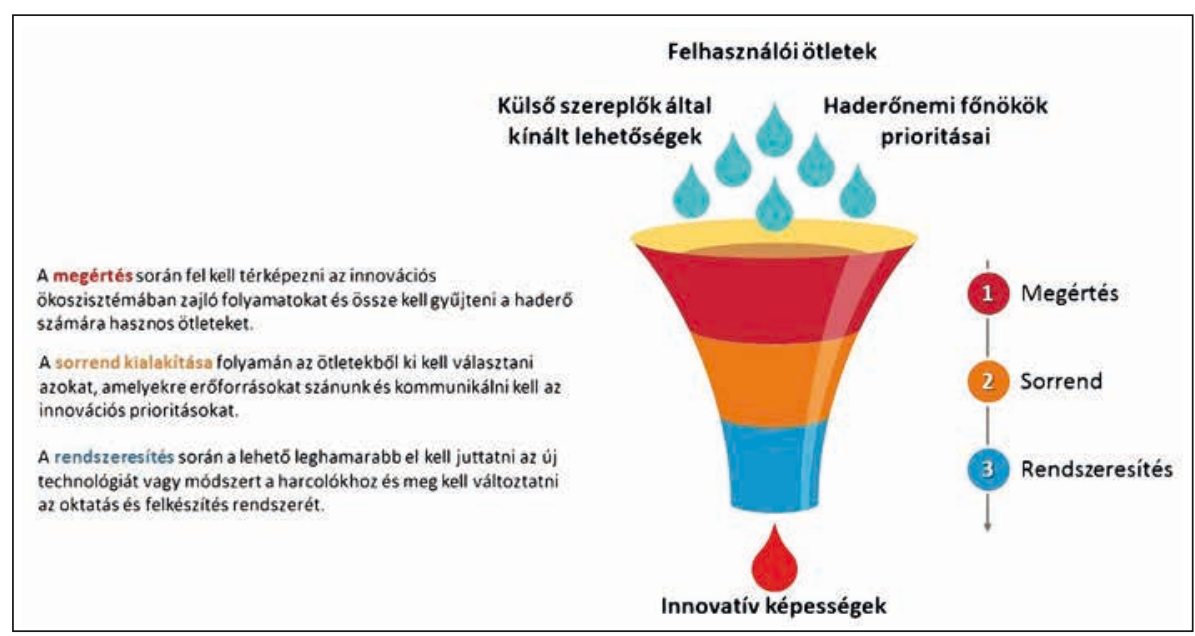

5. ábra. Stratégia által vezérelt innovációs képességfejlesztési folyamat ciós központot létesítve, és ezeket a kirendeltségeket és központokat az innováció forrásának szívébe, a startup-ökoszisztémákba helyezve eredményeket érhetünk el.

$\mathrm{Ne}$ feledjük, ebben a dinamikusan változó világban a Magyar Honvédség számára az a legnagyobb veszélyforrás, ha egyre inkább lemarad a haderő fejlettsége, felszereltsége, és legfőképpen az alkalmazott hadviselési módszertan és az erők, valamint eszközök alkalmazhatóságának tekintetében, azaz nem megfelelő tempóban alkalmazkodik a környezeti változásokhoz és a tecnológiai fejlődésből eredő kihívásokhoz.

na hirtelen integrálni egy gerillamozgalmat a soraiba. Arra feltétlenül számítani kell, hogy amennyiben megvalósul, az első kísérletek nem hozzák meg a várt eredményt.

Az innováció őrületes üteméhez alkalmazkodva új szervezeti formák és struktúrák meghonosításával kísérletezve, a bürokrácián kívüli innovációs kirendeltséget vagy innová-
Éppen ezért van szükség a két kiemelten fontos stratégiai változás azonnali bevezetésére, és stratégia által vezérelt innovációra, amely képes felgyorsítani az emberi adaptációs folyamatokat, a szervezeti kultúra megváltoztatásához szükséges szemléletváltást, illetve a technológiai fejlesztésekre is jótékony hatással van.

\section{JegYZETEK}

1 John Keegan: A hadviselés története. Ford. Bart István. Budapest, Corvina, 2002.

2 Applegate, R. A. D. - Moore, J. R.: Warfare - an Option of Difficulties. A Examination of Forms of War and the Impact of Military Culture. The RUSI Journal, 1990/3, 13-20.

DOI: 10.1080/03071849008445449

3 Forgács Balázs: Napjaink hadikultúrái - A hadviselés elmélete és fejlődési tendenciái a modern korban. Doktori PhD értekezés. Zrínyi Miklós Nemzetvédelmi Egyetem, 2009.

4 Liddell Hart: Stratégia. Ford. Soproni András. Budapest, Európa Könyvkiadó, 2002, 513-515.

5 Kovács Jenő: Magyarország katonai stratégiája. Országos Kiemelésű Társadalomtudományi Kutatások, Budapest, 1995, pp. 22-23.

6 Kovács, 1995, pp. 23-25.

7 Kovács, 1995, p. 24.

8 Unrestricted Warfare (Korlátok nélküli hadviselés) címmel 1999-ben írt egy tanulmánykötetet két kínai ezredes, Qiao (Csiao) Liang és Wang Xiangsui (Vang Hsziangcsuj). Internet: http://www. cryptome.org/cuw.htm [2018.10.01.]

9 Liang, Q. és Xiangsui, W. (1999). Unrestricted Warfare. Peking, PLA Literature and Arts Publishing House, 204-216.

10 Philip Kapusta, The Grey Zone, Special Warfare, 2015 október.

11 Carlota Perez (2003). Technological Revolutions and Financial Capital: The Dynamics of Bubbles and Golden Ages. London: Edward Elgar Pub.

12 Chandler, The Visible Hand' adja a legjobb magyarázatát ennek. Alfred D. Chandler (1993). The Visible Hand: The Managerial Revolution in American Business. New York: Belknap Press.

13 Alfred D. Chandler (2013). Strategy and Structure: Chapters in the History of the Industrial Enterprise. New York: Martino Fine Books.

14 Igor H. Ansoff, Corporate Strategy: An Analytic Approach to Business Policy for Growth and Expansion, New York: McGraw Hill, 1965.

15 Porter M. E. (1980). Competitive Strategy: Techniques for Analyzing industries and Competitors. New York: Free Press. Michael E. Porter: Versenystratégia. Ford. Pollák Tamás, Tényi György Akadémiai, Budapest, 2006.

16 Lee Shan, Florence Lin Yean Yng, George Ofori, Low Sui Pheng, (2012). Military Principles of Chinese Origin to Improve Competitiveness.

17 Eric Kutcher, Kara Sprague, New Corporate Titans are Rising Faster but they are also fadin faster too, https://www.recode. net/2017/7/17/15979206/enterprise-corporate-business-seven-techforces-weapon-tool-network-effects-audience [2018.10.01.]

$18 \mathrm{Az}$ Innosight felmérése „Corporate Longevity: Turbulance ahead for Large Organizations”, amely kiterjed az elmúlt egy évszázadra, az alábbi linken érhető el: https://www.innosight.com/insight/ corporate-longevity-turbulence-ahead-for-large-organizations/ [2018.10.01.]

$19 \mathrm{Ez}$ az a zavaros periódus a robbanásszerű növekedés vége és a fordulópont kezdete közt, amikor az intézményi alkalmazkodás bevezetése szükséges.

20 A világon rendelkezésre álló információ 90\%-át az elmúlt két évben állította elő az emberiség.

21 Az oktatáskutatás egyik kiemelkedő alakja, Tony Wagner egész életét e téma kutatásának szentelte, és hét olyan képességet azonosított, amelyekre feltétlenül szüksége lesz az embereknek a közeljövőben. Ezek a következők: (1) kritikus gondolkodás és problémamegoldás, (2) hálózatépítés és befolyásoláson alapuló vezetés, (3) agilitás és rugalmasság, (4) kezdeményező képesség és vállalkozó kedv, (5) hatékony kommunikációs képesség, (6) információ elemzésének képessége, (7) kíváncsiság és fantázia. Tony Wagner's Seven Survival Skills. Internet: http://www.tonywagner.com/7-survival-skills

22 Miként például a GE Labs, DuPont Labs, Bell Labs, IBM Research, $3 \mathrm{M}$, Xerox PARC és Kodak Labs.

23 Joseph A. Schumpeter (2008). Capitalism, Socialism, and Democracy: Harmadik kiadás. New York: Harper Perennial Modern Classics. DOI: 10.4324/9780203857090

24 Gondoljunk a következő vállalatokra: Apple, Digital Equipment Corporation, Sun Microsystems és Genentech.

25 A nanotechnológia egyre szélesebb körben használatos, az akkumulátoroktól kezdve a gyógyszeriparon át a nagy energiájú robbanóanyagokig. A biotechnológia egyes elemei még a számítási kapacitás költségarányánál is jóval gyorsabban fejlődnek (például az emberi genom szekvenálásának költsége az elmúlt 10 évben 6 nagyságrenddel, az egymilliomodára csökkent. Klaus Schwab, "The Fourth Industrial Revolution: what it means, how to respond," 2016 január 14. Internet: http://www.weforum.org/agenda/2016/01/

26 A védelmi szektorban is megfigyelhető ez a probléma, ahol a NATO-tagországok walesi csúcstalálkozóján létrehozott egyezség szerint a védelmi költségvetés $20 \%$-át kell új eszközbeszerzésre és kutatás-fejlesztésre fordítani, de ezt a tagországok nagy része nem teljesíti. 